\title{
Combatting Disability Discrimination: A Comparative Critique of France and Great Britain
}

Corby, S; William, L and Richard, S.

\begin{abstract}
This article examines disabled people's employment in Great Britain and France. Although both countries have poor rates of employment for disabled people compared to non-disabled people, Great Britain's disabled people's employment rate is lower than France's. Possible explanations include weak enforcement mechanisms in Great Britain, British judicial resistance, the lack of an institutional role for British trade unions resulting in an implementation gap and the proactive form of French law, a quota-levy scheme, which has no British parallel. The conclusions suggest which of these explanations are the most plausible and propose that Great Britain considers adopting some French provisions, thus tempering Britain's voluntarist approach.
\end{abstract}

\section{Keywords}

Disability, employment rates, France, Great Britain, implementation gap, enforcement, judicial resistance, quota-levy, trade unions

\section{Corresponding Author}

Laura William, Department of Human resources and Organisational Behaviour, University of Greenwich, Park Row, Greenwich, SE10 9LS.

Email: L.C.William@Greenwich.ac.uk

\section{Introduction}

Employment is a mark of societal inclusion, but disabled people have a history of social exclusion in many countries, including Great Britain and France, with a higher incidence of working on nonstandard contracts, working part-time hours and earning less than their non-disabled peers (Grammenos, 2013). As we show below however, France has significantly higher rates of employment of disabled people than Great Britain and our research question seeks to understand the explanatory factors for the differing employment rates in the two countries.

We compare Great Britain and France because despite some differences, they exhibit many similarities. Thus, although France has a civil law base and Great Britain has a common law base, both countries are committed to ensuring work for disabled people (Bertrand, 2013; DWP, 2015). Also, both countries are currently covered by European Union (EU) disability law (Directive 2000/78 EC) and subscribe to the European Commission's Disability Strategy 2010-2020 (European Commission, 2010).

Our research objective is to consider possible explanations for these two countries' differing employment rates of disabled people. To do so, we draw on official materials, statutes, handbooks, case law and legal commentaries in English and French. This analysis, which was carried out by French and English-speaking researchers who were familiar with the equality context in both countries, was supplemented by some expert interviews: five in France and four in the UK to clarify law and public policy. To this end, we draw on employment law, labour economics, industrial relations and industrial sociology and the plan of this article is as follows. First, having looked at some comparative statistics, we deal with the form of the law and judicial resistance. Then we turn to 
enforcement by the state, by individuals and by trade unions. Next, we consider labour market activation policies, finally discussing our conclusions.

\section{The statistics: disabled people's employment}

The statistics shown here are taken from a pan-European survey, the European Union Statistics on Income and Living Conditions (EU-SILC) facilitating international comparison and we focus on employment per se. Consideration of economic inequality and occupational segregation, important as they are, is beyond the scope of this article.

The EU-SILC survey defines a disabled person as a person who reports that they are limited in the activities they usually do because of health problems for at least the last six months and covers all individuals over the age of 16 living in private households (i.e. not institutionalized). Also, it covers the United Kingdom (UK), although this article focuses for the most part on Great Britain,

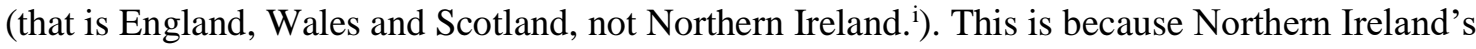
disability law differs somewhat from Great Britain's.

Table 1 shows that 46 per cent of disabled people aged 20- 64 are employed in the UK compared to 54 per cent in France and that there is an employment gap of 34 per cent between disabled and non-disabled people in the UK compared to 19 per cent in France. Table 1 also differentiates by gender. As shown, disabled women in both countries face a double disadvantage: a lower employment rate than non-disabled women and a lower employment rate than disabled men.

'Table one about here'

'Table two about here'

Table 2 distinguishes between moderately disabled people and severely disabled people. These figures are also based on self-report, and as noted above, the survey asked about 'limitation in activities people usually do because of health problems for at least the last 6 months', but for Table 2 the possible answers were: 1 . yes, strongly limited; 2 . yes, limited; 3. no, not limited. These figures show that although moderately disabled people are more likely to be employed in the UK than in France, severely disabled people are more likely to be employed in France than in the UK.

'Table three about here'

In both countries, the employment rate for disabled people and all people peaks at 35-44 years. The employment rate of disabled people in the UK, however, is lower than that of France at all ages except 16-24, although the gap reduces in the 55-64 age group.

The EU-SILC statistics have been used because they are the only available statistics providing a cross national comparison on the disability employment rate, but as noted above they are based on self-report and the subjective view of respondents who may inflate the incidence and severity of their health problem to rationalize labour force non-participation and the receipt of disability benefits. Benitez Silva et al., (2004), however, in an American study, found that overall individuals' evaluation of their disability was on average the same as the Social Security Administration's evaluation of that disability: although many seemed to inflate the evaluation of their disability, just as large a part of the population did exactly the opposite. That study though was intra-country and cross-country comparisons are more problematic, as self-report may be influenced by social and cultural factors and the benefit system (OECD, 2016). For example, Groot (2000) showed that Danish and Swedish respondents tended to largely over-rate their health, while Germans tended to under-rate their health.

Bearing in mind these limitations, the EU-SILC survey suggests that disabled people are more likely to be employed in France than in the UK irrespective of gender and we now seek to understand explanations for this variation. 


\section{Legal regimes}

A possible explanation for variation between Great Britain and France in respect of disability employment is the form of the law in the two countries. One form is command and control which posits that a rational individual will try to avoid sanctions (Tyler and Blader, 2005) but this can engender resistance and adversarialism, thus creating unintended harm resulting in reduced employment outcomes for minority groups (Maroto and Pettinicchio, 2014). Another form is selfregulation which posits that individuals internalize rules and choose to follow them without rewards and sanctions (Tyler and Blader, 2005), but the extent to which this is done will vary between organisations. A third form, which avoids command and control and self-regulation, is to shape the law to 'nudge' employers to behave in a certain way (Thaler and Sunstein, 2008). Thaler and Sunstein argue that this combines libertarianism, (as actors are free to choose), with paternalism, (as actors are influenced in a way that contributes to a government's goal), and immodestly they claim that the deployment of 'both incentives and nudges...can help solve many of society's major problems' (Thaler and Sunstein, 2008:9). Against that background, we now look at two different legal approaches.

\section{The French quota-levy scheme}

France has a quota-levy scheme which has no British parallel. Private sector companies and public authorities in France employing 20 employees or more are obliged to employ 6 per cent of disabled people among their total workforce. The quota system was introduced in 1924 and was 10 per cent of the total workforce until 1957, when it was reduced to 3 per cent between 1957 and 1987 (Romien, 2005). It was then raised to 6 per cent from 1987. We have been unable to discover the reason for the percentage figure. ${ }^{\text {ii }}$

The workers included in the quota are those who have obtained official recognition of their disability, known as the Recognition of the Quality of a Disabled Worker (RQTH), which is granted to those aged 16 and over with no upper age limit, for one to five years, on a renewable basis and applies to employees and volunteers (Ferri and Lawson, 2016). A decision on RQTH is made by the Commission des Droits et de l'Autonomie des Personnes Handicapées (CDAPH) after advice from a multi-disciplinary team, although RQTH is granted automatically to those with an invalidity or occupational injury pension. In 2014, 95 per cent of disabled workers' recognition demands were accepted (Barhoumi and Chabanon, 2015:12).

Those officially recognized are only obliged to inform the employer of their RQTH status if they wish to do so, for instance to seek adjustments to their working conditions or workplace. Klarsfeld et al (2012: 315), however, maintain that employers 'encourage workers to disclose hidden impairments, sometimes offering financial incentives' in order to meet the quota.

To comply with the quota, employers can directly employ disabled people and/or include disabled workers in sheltered employment or disabled independent workers who provide goods and services to them for up to half the quota ( 3 per cent of their workforce). They can also take on disabled people as trainees under the Vocational Training Act of up to 2 per cent of the workforce. Another way that employers can meet the quota is to conclude an approved joint agreement setting out how they will promote the employment of disabled people. We return to these agreements below.

Employers who fail to fulfill their quota in full or in part must pay a levy to the Association de Gestion du Fonds pour l'Insertion Professionnelle des Personnes Handicapées (AGEFIPH), the body responsible for collecting the levy from private sector employers, or to Le Fonds pour l'Insertion des Personnes Handicapées dans la Fonction Publique (FIPHFP), its public sector equivalent. France's levy at the time of writing equates to 400 times the hourly minimum wage per missing disabled employee for organisations with 20 to 199 employees, 500 times the hourly minimum wage for organisations with 501 to 749 employees and 600 times the hourly minimum wage for organisations with 750 plus employees. Since 2009, where organisations have made no improvement in the number of disabled people they employ directly or through contracting out in a three year period, the levy is increased to 1,500 times the hourly minimum wage per missing disabled 
employee. In 2012, 22 per cent of private sector companies only paid the levy; 27 per cent of companies met the quota fully by directly employing disabled workers, 11 per cent had an approved agreement, while 40 per cent had at least one disabled employee and/or sub-contracted and/or paid the levy in part. (AGEFIPH, 2015a).

Waddington (2000) argues that the quota system is philosophically flawed: it assumes that only if employers are obliged to hire disabled workers (or pay a levy instead) will they do so and that the protected group is inferior. Similarly, Sargeant et al (2016) criticize quota systems for sending out mixed messages: on the one hand, the employment of disabled people is desirable, but on the other hand disabled people are unable to compete on equal terms. Furthermore, quota systems focus on the number of disabled people employed, rather than their skills and position in the organisation's hierarchy.

Waddington (2000:41) admits, however, that quota schemes 'are frequently popular with people with disabilities' and Grammenos (2013: 5) points out that the six EU countries with the lowest activity gap between disabled and non-disabled people all have quotas: Austria, Germany, France, Italy, Luxembourg and Slovenia.. Furthermore, Fuchs (2014) says that according to available empirical data, quota systems lead to small net employment gains for disabled people, a point with which Sargeant et al (2016: 14), when examining quota schemes in Italy and Russia, tentatively agree, saying that "quota systems may help to increase the participation of disabled people in the labour market'.

Meziani et al. (2014) submit that quota schemes could cause discrimination between disabled people as the employer might be more willing to hire people with a minor impairment to meet the quota, instead of a more severely disabled person. Table 2, however, indicates that more severely disabled people are employed in France, where there is a quota-levy scheme, than in the UK where there is no such quota-levy.

\section{Great Britain's public sector equality duty}

Great Britain, unlike France, has a Public Sector Equality Duty (PSED) (Equality Act, 2010, s.149). The PSED is based on the premise that the causes of discrimination and inequality are deeply rooted in societal structures and institutions and positive duties change the focus from individual wrongdoing to focus on the organisations in the best position to promote equality (Fredman, 2012). Under the PSED public sector bodies have a general duty to have 'due regard' to three matters: first, the elimination of discrimination, harassment, victimisation and 'any other conduct' prohibited by law; second, the advancement of 'equality of opportunity between those who share a relevant protected characteristic and those who do not share it' and third, the fostering of 'good relations between those who share a relevant protected characteristic and those who do not' ${ }^{\text {iii }}$ Public sector bodies are required to publish annual information to demonstrate their compliance. Alongside the general duty are specific duties, which vary in England, Scotland and Wales, with England's being the least prescriptive.

The PSED has a number of defects. First, the duty does not relate to private bodies exercising purely private functions, whereas the French quota-levy scheme has no such limitation. Second, the duty lacks clarity. For instance, bodies covered by the general duty must have 'due regard' to the elimination of discrimination, but it is not clear what 'due regard' means. Third, under the English regulations, organisations are not required to carry out monitoring or an equality impact assessment or consult with trade union equality representatives (unlike the equivalent Welsh and Scottish regulations). Fourth, the PSED is enforceable only by way of judicial review and does not give rise to any private law rights.

The PSED has been criticized by commentators of different political complexions. For instance, a Government commissioned review found: 'In far too many cases we have uncovered useless bureaucratic practices which do nothing for equality' (Government Equalities Office, 2013: 6), while Fredman (2011: 427) said: 'Without a duty to take action, the risk of proceduralism is difficult to overcome'. 


\section{Judicial resistance}

A further potential explanation is that the variation in disabled people's employment rates in France and Great Britain depends not only on the form of the law, but also on the extent to which there is judicial resistance and conservative judgments in the nation's courts, resulting in the law failing to secure adequate outcomes for minorities (Maroto and Pettinicchio, 2014). Tokson (2015) argues that judges may be motivated to resist legal change as they develop biases in favour of the law they have repeatedly applied and justified, while Machura (2016) argues that judges may be tempted to support the powerful rather than the disadvantaged.

In Great Britain, there are examples of restrictive judicial interpretations of the legislation that makes it very difficult for a disabled person to win a case and here we give just two egregious examples: Quinlan v B\&Q plc (1998) and London Borough of Lewisham v Malcolm (2008). In the former case, the Employment Appeal Tribunal held that Quinlan was not disabled as he could lift every-day objects, even though he could not lift the objects he was required to lift at his workplace. In the latter case, the House of Lord, by a majority, held that Malcolm's comparator was a non-disabled person, not another disabled person. It took further legislation to obviate that judgment. Yet some judicial decisions have expanded the interpretation of British law. For instance in Archibald v Fife Council (2004), the Supreme Court held that the duty to make a reasonable adjustment for a disabled person could extend to placing that person in a post of the same or a higher grade without a competitive interview. In Coleman v Atteridge Law (2007) an employment tribunal asked the European Court of Justice whether protection against discrimination should be extended to a carer of a disabled person ${ }^{\text {iv }}$ and this eventually resulted in associative discrimination being outlawed throughout the EU.

In France there is far less opportunity for judicial resistance than in Great Britain, as the main avenue for individual enforcement in discrimination issues is not through the courts, but through the Défenseur du Droits (DDD), which is akin to a mediation body staffed by investigators who are not professional judges. In short, the DDD investigates complaints from individuals of less favourable treatment, harassment, associative discrimination and failure by the employer to make a reasonable accommodation and then makes a recommendation, albeit of a persuasive, not legally binding nature.

A complainant dissatisfied with the decision or recommendation (and the DDD resolves most complaints) can take their case, if in the private sector, to a labour court (Conseil de Prud'hommes); public servants can take a case to the administrative tribunal and any individual can file a complaint. with the crown prosecutor, the police or the senior examining magistrate of the crown court (Tribunal de Grande Instance). Unfortunately, there are no statistics which indicate how many disability discrimination cases are adjudicated by these bodies, but anecdotal evidence suggests only a small number.

\section{Enforcement mechanisms}

It is argued that stronger law will not necessarily lead to improved outcomes for minorities, what is needed is stronger implementation 'to give substantive effect to formal rights, reducing the likelihood of adverse treatment and promoting fairer workplaces' (Dickens, 2012:1). If enforcement mechanisms are weak, the law will be 'like paper tigers, fierce in appearance, but missing in tooth and claw' (Hepple, 2002:238).

There are various forms of enforcement: first is state enforcement, which requires the state and state agencies to be adequately funded if law breakers are to be successfully identified and punished. In addition, state agencies can encourage, but not require, employers to behave in certain ways but if compliance is not forthcoming they can impose sanctions. Second, there is individual enforcement. Third, there is enforcement by trade unions. Trade unions can mediate the law directly by taking cases on behalf of members. They can also have an indirect effect on equality, through equality representatives and collective bargaining (Bacon and Hoque, 2012). 


\section{State enforcement}

Dealing first with Great Britain, a state agency, The Equality and Human Rights Commission (EHRC), has the power to conduct inquiries and formally investigate specific organisations and can issue an Unlawful Act Notice, which may include an action plan; (there is a right of appeal to an appropriate court or tribunal.) In addition, the EHRC can make agreements even if it has not conducted a formal investigation. It can also enforce the specific duties of the PSED by issuing a noncompliance notice.

Whatever the EHRC's powers in theory, in practice they are weak. First, an Unlawful Act Notice or Non-Compliance Notice created by the EHRC cannot be enforced by the EHRC itself and necessitates an application to the civil courts. Indeed, the EHRC favours agreements in lieu of investigations and has, to date, not issued any Non-Compliance Notices (EHRC, 2016a; EHRC, 2016b). Secondly, the EHRC's investigations are often general, rather than organisation specific and lead to general recommendations, not sanctions (O'Brien, 2012). Thirdly, these powers have been little used in the employment context. These enforcement failures may be partly because of budget cuts. The EHRC had a budget of $£ 70$ million per year when it was established in 2007, which was cut to $£ 17.1$ million per year in 2016-17 (Pring, 2016).

Turning to direct state enforcement in France, there are labour inspectors who are authorised to uncover unlawful acts in matters of discrimination under the Criminal Code. There are no statistics available, however, on labour inspectors' activities in respect of disability employment. French state agencies are also involved in enforcing the quota-levy scheme. If an organisation does not fulfil its quota, it must pay a levy and the higher the levy, the more a rational organisation will choose to fulfil its quota and thus meet the aim of French public policy. Increasingly French employers are meeting the quota: the percentage of companies directly employing disabled people rose from 60 per cent in 2005 (DARES, 2007:4) to 78 per cent in 2014 (DARES, 2016a).

\section{Individual enforcement}

In both countries, disabled people have the right to not be discriminated against in employment. Importantly, the law in both countries requires the employer to make 'reasonable adjustments' or to take 'appropriate measures' to quote the British and French phrases respectively, in order to enable disabled people to have access to, or retain employment, unless the adjustment/measure would impose a disproportionate burden on the employer. These rights, however, have to be enforced by individuals and in Great Britain this is through employment tribunals, but this enforcement mechanism has flaws.

First, where British individuals make a claim to an employment tribunal they had to pay fees of $£ 1,200$ from 2013 until quashed in 2017 when the Supreme Court held that the fee system was inconsistent with access to justice. Interestingly, the government admitted that fees had had 'a greater financial impact on people with disabilities compared with people who do not have a disability' (Ministry of Justice, 2017:50).

Second, British claimants have to marshal the evidence and navigate legal complexities. including an adversarial procedure with cross-examination at its heart. Also, they first have to establish that they are disabled, meeting a legal definition which, is narrower and more complex than the French definition. Indeed, Lawson (2011: 362) maintains that 'defendants often deliberately choose to challenge the disabled status of a claimant as a strategy for ... pressurising them into settling or withdrawing the case'. Moreover, perhaps unsurprisingly, in view of the intricacy of the legislation, British claimants are unlikely to win their case: in the three months from April 2015 just five per cent of disability discrimination claims were successful (Ministry of Justice, 2016). Finally, even when disabled claimants do succeed, the remedy is compensation, not reinstatement, even if an employment tribunal has held that they have lost their job as a result of disability discrimination. Moreover, such compensation is normally unlikely to be substantial: the median award was $£ 11,309$ in 2015-16. (Clark, 2016). 
In contrast, France's DDD has always been free to claimants, and if French claimants do not accept a DDD recommendation they can go to the Conseil de Prud'hommes, that is now free too. (Formerly it was only €35.) Also, it is strongly arguable that the DDD's investigative approach is less stressful for French claimants than the adversarial, cross-examination based approach in Great Britain's employment tribunals. Furthermore, whereas British claimants have a poor adjudicative success rate, 80 per cent of the cases that the DDD investigates are resolved (DDD, 2014). Moreover, the DDD, unlike many British private mediation bodies, publishes its decisions which include an examination of the complaint in the light of the law, so norms are articulated.

\section{Trade union enforcement}

Having considered state enforcement and individual enforcement, we now turn to trade union enforcement. British trade unions support their disabled members through workplace casework and by providing legal representation for those wanting to claim disability discrimination at an employment tribunal, although we have not found any statistics.

In addition, there are some 1,400 trade union equality representatives in British workplaces (TUC, 2010) and their role is to encourage employers to improve equality policies and practices, offer independent advice on equality issues to employees, monitor the employer's policies and practices, and raise the profile of the equality agenda within their unions and workplaces. Bacon and Hoque (2012) found that over three-fifths of equality representatives reported having had a positive impact on their employer's disability practices and also were more likely to report having more influence on disability policies than on any other equality strand (Bacon and Hoque, 2012).

British trade unions have also appointed so-called disability champions, of which there over 500. Bacon and Hoque (2015) found that 71 per cent reported 'a lot' or 'some' influence on employer willingness to conduct disability audits of documents, buildings or procedures and 57 per cent reported 'a lot' or 'some' influence on employer equal opportunities practices with regard to disability. In addition, one trade union, the Transport and Salaried Staffs Association (TSSA), appointed some 80 neuro-diversity champions who achieved some success in influencing employer disability practices, for instance obtaining workplace adjustments (Richards and Sang, 2016).

Importantly however, union equality representatives, disability champions and neurodiversity champions do not have a statutory right be consulted, to have paid time off to carry out their duties or to have office facilities, unlike other categories of British trade union representatives. Moreover, although the government initially funded TUC training for disability champions and TSSA support for its neuro-diversity champions, this funding has now been withdrawn.

In contrast, French trade unions, unlike British trade unions have a significant disability role enshrined in law. First, they have seats on the CDAPH, the body mentioned above which is responsible for recognising a person's disabled status and on the governing boards of the AGEFIPH (2015b) and the FIPHFP (2015), setting policy on the expenditure of the funds collected from the levies on employers who have not met the quota.

Second, staff representatives (délégues du personnel), who are in theory mandatory in firms of 11 employees or more, have a right to draw the attention of management to any breach of employees' individual rights (droit des personnes), a broad notion encompassing employees' physical and psychological wellbeing and 'individual liberties' at work ${ }^{\mathrm{v}}$. If no resolution is possible at the workplace, a Conseil de Prud'hommes may hear the dispute (private sector only). In such cases, the judges may issue an order which could include requiring management to conduct an investigation with staff representatives. Third, most French trade unions help all individuals who wish to take a case, (not just union members as in Great Britain).

Fourth, French trade unions have a role in collective bargaining through information and consultation bodies. This has a disability dimension because employers and trade unions have to negotiate annually on disability at enterprise level ${ }^{\mathrm{vi}}$ and every three years they have to negotiate on the subject at a sectoral level. ${ }^{\text {vii }}$ Accordingly, French employee representatives can conclude joint agreements with the employer to promote the employment of disabled people. These essentially spell 
out the ways in which the quota is to be met and/or how money that the employer would otherwise have to pay to AGEFIPHP/FIPHP is to be spent, but such enterprise level agreements have to be approved by a state agency, the Directions Régionales des Entreprises, de la Concurrence, de la Consommation, du Travail et de l'Emploi (DIRRECTE). See the agreements at Accor, Carrefour and Sodexo (International Labour Office, 2010) and more recently at Renault. ${ }^{\text {vii }}$ Agreements can also be made at national and sectoral level in which event they have to be approved by the Délégation Générale à l'Emploi et à la Formation Professionnelle (DGEFP). A study found that such joint agreements promote the implementation of disability policies and also facilitate social dialogue between employers and trade unions, as disability is a unifying topic (DARES, 2016b).

Nevertheless, even though disabled people's employment is a topic in negotiations, it is often marginal (Maggi-Germain, 2010). Furthermore, such collective agreements are uncommon: only 11 per cent of companies signed such agreements in 2012 (AGEFIPH, 2015a). In particular, small companies often find it difficult to dedicate human resources to such negotiations, although there is some evidence that this is a prerequisite for the implementation of a disability agreement (MaggiGermain 2010).

Moreover, even if there are joint agreements, they are not without shortcomings. First, they can be used primarily as a means to enhance the company's brand, rather than to make significant advances in respect of the integration of disabled people into the workforce (Blatge, 2010). Second, according to Barel and Frémeaux (2012) companies may adopt reactive strategies, for instance employing disabled people directly or indirectly only to offset the payment of the disability levy as opposed to adopting proactive strategies, for instance making the diversity dimension a key plank of their human resource management. Nevertheless, whatever their shortcomings, collective agreements are even rarer and less specific in Great Britain than in France and, where they are found, as in local government, they are confined to an equal opportunities clause which includes a reference to disability (EurWork, 2001).

\section{Labour activation policies}

As Kahn Freund (1969: 311) said: 'Many people have something like a magic belief in the efficacy of the law in shaping human conduct and social relations. It is a superstition'. Similarly, Hepple (1992) submits that law is both too specific and too selective to deliver substantive equal rights. Therefore, part of the explanation for the higher employment rate of disabled people in France compared to the UK is not to be found in the law, but could be in labour activation policies, particularly training and the provision of aids, which are aimed at increasing the supply of disabled employees.

In France, the budget for labor activation policies for disabled people comes from the levy and is ring-fenced and thus not subject to any government cuts and the state agencies, AGEFIPH or the FIPHFP, are responsible for redistributing the levy. In 2014, AGEFIPH spent more than $€ 60$ million on training disabled people, more than $€ 100$ million on employment integration including providing disabled people with advice on job searching, and more than $€ 92$ million on job retention, for instance advising companies and providing finance for workplace adjustments (AGEFIPH, 2014). This entailed financially contributing to 71,277 work placements, 18,669 job retentions and 2,569 apprenticeship contracts in favor of disabled individuals (AGEFIPH, 2014).

In Great Britain too, grants can be provided to help disabled people obtain or stay in work, but such provision is fragmented. The main vehicle is the Access to Work provides advice and financial support for disabled employees and their employers to implement alterations to the workplace, for instance special equipment, fares to work if public transport cannot be used and disability awareness training. The most common type of adjustment is time related or part -time work requests (William, 2016); in such instances Access to Work may advise the employer how to implement these adjustments, but despite Access to Work's involvement, adjustments are usually slowly implemented (William, 2016).

In 2015-16 32,150 disabled people benefitted from Access to Work, and although Access to Work programme expenditure 'is not routinely published' it is known that in 2013-14 expenditure was £108 million (Clarke, 2016:3). This compares poorly with AGEPIFH’s expenditure. 
Moreover, in contrast to the ring-fenced money in France, these British Access to Work grants are subject to government cuts. For instance, in March 2015, the Government announced changes to the scheme: a cap of $£ 40,800$ per disabled person, calculated at one and a half times annual salary, uprated annually (Clarke, 2016). ${ }^{\text {ix }}$

Access to Work, however, is not the only government funded vehicle to support disabled people's employment. The government funded Work Choice programme in turn funds public, private and voluntary organisations to deliver work entry and in-work support, as does the Work Programme which covers all those unemployed, not just disabled people and also is delivered by a range of providers. Both the Work Programme and the Work Choice Programme are to be replaced by a Work and Health Programme, again using a range of providers and not solely targeted at disabled people.

In France, labour activation policies include the state's provision of sheltered employment.

This is based on the premise that those with severe impairments are capable of economically valuable work. In 2012, 118,211 disabled workers were employed in an Etablissement et Service d'Aides par le Travail (ESAT) with 'a legal status similar to employees' (Policy Department A, 2015: 22) for people with one third or less work capacity loss. Arguably sheltered employment permanently 'ghettoizes' disabled workers, as 'there has been a notable lack of success in moving disabled workers to the open labor market' (Waddington, 2000:42), partly due to a lack of relevant training possibilities (Baret, 2013) and only 3 per cent of those in ESATs move into the open market (Policy Department A,. 2015: 27. ESATs also find it difficult to reconcile their economic and socio-medical objectives (Baret, 2012).

In a partial move away from sheltered employment, French businesses can adapt part of their premises for disabled workers, called Enterprises Adaptées which provide semi-sheltered employment. Such adapted businesses employed 31,000 disabled people in 2014 (AGEFIPH, 2015a). In contrast to France, Great Britain has moved away from government owned sheltered employment, known as Remploy factories, as by 2013 it had closed or sold Remploy's factories, whilst its employment service, aimed at enabling disabled people to take up non-sheltered employment, was privatized (BBC, 2014). Remploy now focuses on a return to work service which helps disabled people become 'work ready' while simultaneously advising employers about how to recruit and retain disabled people.

\section{Discussion and conclusions}

This article focuses on employment rate as a measure of disabled people's (in)equality. It appreciates that there are other important measures, particularly the extent of occupational segregation and comparisons of income levels, but they are beyond the scope of this article. Furthermore, we focus on industrial relations explanations (employment law/labour economics/industrial sociology), not wider social factors such as disabled people's access to education, public transport and adapted housing, although acknowledging that such factors have a mediating role in respect of disabled people's employment (Levet, 2007; Blanc, 2009; Jacquinot, 2009).

This article has noted that both in the UK and France disabled people's employment rate is significantly lower than non-disabled people's employment rate, but France's rate of disabled people's employment is higher than the UK's, although these statistics have limitations as discussed above. Against that background we return to our research question and consider explanations for this difference, but because a counter-factual cannot be constructed, we can only indicate those explanations that we find the most plausible.

First, we considered whether the difference stems from the form of the law. As shown above, the key plank of the French approach is the quota-levy scheme and this seems to have some positive implementation effect as evidenced by the growing number of employers directly employing disabled people as the law nudges, but does not command French employers to behave in a certain way (Thaler and Sunstein, 2008). The British approach to 'nudging' is the PSED, but it is inadequate: it does not cover the private sector; its wording is ambiguous and there is no 'carrot' for employers unlike in France. Accordingly, we think the form of the law is a plausible explanation for the differing disabled person's employment gap in the two countries. 
Second, we considered judicial resistance and we have shown how there are many more opportunities for judicial resistance in Great Britain than in France, because whereas in Great Britain the main avenue for complainants is the courts, in France the main avenue is a non-judicial investigative body, the DDD. Yet while we have given examples of judicial resistance in Great Britain, there are examples of judicial decisions which advance the interpretation of disability legislation. ${ }^{\mathrm{x}}$ Accordingly, we do not think judicial resistance is a plausible explanation for the differing disabled person's employment gap in Great Britain and France.

Third, enforcement provides another avenue for explanation: we have shown that in Great Britain there is an implementation gap as the EHRC has never applied sanctions for non-compliance, although empowered to do so (EHRC, 2016a) and British individuals face problems bringing a case to an employment tribunal where they have to adopt an adversarial approach based on cross-examination and, in any event, are most unlikely to win. In contrast, in France state agencies enforce the quotalevy scheme and individuals enforce their rights through a complaint to the DDD which investigates and makes a recommendation to the parties. As to trade union enforcement, although French trade unions have an institutionalised role in implementation, unlike their British counterparts, French collective agreements are uncommon and those that are concluded have shortcomings. Accordingly, whereas trade union enforcement does not offer a plausible explanation for France's greater proportion of disabled people in employment compared to Great Britain's, its mode of both state and individual enforcement may do.

Finally, we consider that labour activation policies are a plausible explanation: in France, the money from the levy is ring fenced. In contrast the British government has a fragmented approach to supporting disabled people's employment, such funding is not ring fenced and what information we have found suggests that there is significantly less money devoted to it, compared to France.

To summarize, the form of the law, enforcement mechanisms by the state, and/or by individuals and labour activation policies are the most plausible explanations for disabled people's higher rate of employment in France compared to Great Britain. We add that these factors are not mutually exclusive, responding to the call for research to consider multiple explanations for the disadvantage of minority groups (Maroto and Pettinicchio, 2014).

In conclusion, and in the light of the finding that the six EU countries with the lowest activity gap between disabled and non-disabled people have quota schemes (Grammenos, 2013), we propose that further research should be undertaken to test these hypotheses and, in particular, to explore whether a quota-levy scheme on the French model could be used to enhance, not replace Great Britain's current legislation, thus tempering its voluntarist approach.

\section{Acknowledgements}

We would like to thank the editor for all his help and encouragement and the referees for their useful comments.

\section{Funding}

The first two authors received no financial support for the research, authorship and/or publication of this article. The third author received a grant from the FNEGE (Fondation Nationale pour l'Enseignement de la Gestion en Entreprise) for a month's maintenance at the University of Greenwich under the mentorship of the first author, when she was a $\mathrm{PhD}$ student and when the research for this article commenced.

\footnotetext{
${ }^{i}$ Northern Ireland's population is a mere 3 per cent of the UK's

ii Loi n'87-517 du 10.7 1987. Italy's disabled quota is 7 per cent of the workforce and Germany's is 5 per cent, having been reduced from 6 per cent (Lee and Lee, 2016, Policy Department A, 2015)

iii See Equality Act 2010, s.149
} 
iv Malcolm v Lewisham LBC [2008] 1 AC 1399, Quinlan v B\&Q plc (1998) EAT 1386/97; Archibald v Fife [2004] 4 All ER 303, Coleman v Attridge Law [2007] IRLR 88.

${ }^{v}$ art. L.2313-2; L.2323-78; L.4131-2 of the labour code

vi art L.2242-13 and L.2242-14 of the Labour Code

vii art L.2241-5 and D.2241-8

viii http://media.renault.com/global/en-

gb/renaultgroup/media/pressrelease.aspx? mediaid $=52096 \&$ nodeid $=129 \& u t m \_c a m p a i g n=r s s \_c o m m$ uniqu\%E9s\%20de\%20presse\%20et\%20dossiers\%20de\%20presse\&utm_medium=rss\&utm_source= media.renault.com

[accessed 3.10.2015].

${ }^{\text {ix }}$ Ministerial statement 12.3.15 HCWS372 http://www.parliament.uk/business/publications/writtenquestions-answers-statements/written-statement/Commons/2015-03-12/HCWS372/ [accessed $5.10 .15]$

\section{References}

AGEFIPH (2014) Rapport d'Activité 2014. France: AGEFIPH.

AGEFIPH (2015a) Publications et études, Les personnes handicapées et l'emploi, chiffres clés Juin 2015. France: AGEFIPH.

AGEFIPH (2015b) Rapport d'Activité 2015. France: AGEFIPH

Bacon N and Hoque K (2012) The role and impact of trade union equality representatives in Britain. British Journal of Industrial Relations 50(2): 239-262.

Bacon N and Hoque K. 2015. The influence of trade union Disability Champions on employer disability policy and practice. Human Resource Management Journal 25(2): 233-249.

Barel Y and Fremeaux S (2012) Les attitudes face à la contrainte légale. RIMHE: Revue Interdisciplinaire Management, Homme ( $s$ ) \& Entreprise 2(2): 33-49.

Baret C (2012) Les établissements et Services D'aide Par Le Travail (ESAT) Parviennent-Ils à Concilier Objectifs économiques et Missions Médico-Sociales? Une Proposition de Matrice Stratégique. RIMHE: Revue Interdisciplinaire Management, Homme (s) \& Entreprise 2(2): 66-82.

Baret C (2013) La Formation Permanente Des Travailleurs Handicapés: Vers Une Nouvelle Place Du Travail Dans La Mission Médico-Sociale? Formation Emploi 123: 67-88.

Barhoumi M and Chabanon L (2015) Dares, Synthèse Stat : Emploi et Chômage des Personnes Handicapées, Novembre 2015. France: DARES.

BBC (2014) Remploy employment services to be privatised. Available at: http://www.bbc.co.uk/news/uk-politics-28417882 (accessed 6 October 2015).

Benitez-Silva H, Buchinsky M, Man Chan H, Cheidvasser S and Rust J (2000) How large is the bias in self-reported disability? NBER Working Paper 7526. Cambridge, MA: National Bureau of Economic Research.

Bertrand L (2013) Politiques sociales du handicap et politiques d'insertion : continuités, innovations, convergences. Politiques Sociales et Familiales 111: 43-53.

Blanc A (2009) L'insertion professionnelle des travailleurs handicapés. Presses Universitaires de Grenoble.

Blatgé M (2010). Le handicap: objet de négociation collective ou de communication? La Revue de l'IRES 67: 123-136.

Clark I (2016) Employment tribunal awards statistics 2015-2016. Available at: www.morton fraser.com/knowledge-hub/employment-tribunal-awards-statistics-2015-2016 (accessed 26 June 2017).

Clarke J (2016) Access to Work scheme for people with disabilities. London: House of Commons Library.

DARES (2007) L'Emploi des Travailleurs Handicapés dans les Etablissements de 20 Salariés et Plus. Bilan de L'Année 2005. Report, Paris: DARES. 
DARES (2016a) L'obligation d'emploi des travailleurs handicapés en 2014:Un taux d'emploi direct en légère hausse, Dares Résultats, Novembre $2016 \mathrm{~N}^{\circ} 066$.

DARESb (2016b) Entreprises et handicap, les modalités de mise en œuvre de l'OETH, Dares Document d'études, septembre $2016 \mathrm{~N}^{\circ} 201$.

DDD (2014) Rapport annuel d'activite 2014. Report, France: DDD.

Dickens L (2012) Fairer workplaces: making employment rights effective. In: Dickens L (ed) Making Employment Rights Effective. Oxford: Hart Publishing, pp. 205-288.

DWP (2015) New Measures to Support More Disabled People into Work. Available at: https://www.gov.uk/government/news/new-measures-to-support-more-disabled-people-intowork (accessed 10 August 2016)

EHRC (2016a) Freedom of information request. https://www.whatdotheyknow.com/request/321914/response/787544/attach/7/FOI971\%20Wil liams\%2020160324\%20Response.pdf. (accessed 10 August 2016)

EHRC (2016b) Inquiries, investigations and wider powers. Available at: https://www.equalityhumanrights.com/en/our-powers/inquiries-investigations-and-widerpowers (accessed 29 July 2016).

European Commission (2010) European Disability Strategy 2010-2020: A Renewed Commitment to a Barrier-Free Europe. Brussels: European Commission.

EurWork (2001) Workers with disabilities, law, bargaining and the social partners. Dublin: European Foundation for the Improvement of Living and Working Conditions.

Ferri D and Lawson A (2016) Reasonable accommodation for disabled people in employment. A legal analysis of the situation in EU Member States, Iceland, Liechtenstein and Norway. Report, EU: European Commission.

FIPHFP (2015) Rapport d'Activité 2015. France: FIPHFP

Fredman S (2011) The Public Sector Equality Duty. Industrial Law Journal 40(4): 405-427.

Fredman S (2012) "Breaking the mold: equality as a proactive duty". The American Journal of Comparative Law 60(1): 265-288.

Fuchs M (2014) Quota Systems for disabled Persons: Parameters, Aspects, Effectivity. Policy Brief March 2014, Vienna: European Centre for Social Welfare Policy and Research.

Government Equalities Office (2013) Review of the Public Sector Equality Duty: Report of the Independent Steering Group. London: Government Equalities Office.

Grammenos S (2013) European comparative data on Europe 2020 and people with disabilities. In: Centre for European Social and Economic Policy and ANED (eds). Cornell University: Cornell University ILR School

Grammenos S (2014) European comparative data on Europe 2020 and people with disabilities, final report for the ANED. Leeds: University of Leeds.

Groot W (2000). Adaptation and scale of reference bias in self-assessments of quality of life. Journal of Health Economics. 19(3): 403-420.

Hepple B 1(992) Have 25 years of the Race Relations Act been a failure? In: Hepple B and Szyszczak E (eds) Discrimination and The Limits of the Law. London: Mansell, pp.19-34.

Hepple B (2002) Enforcement: the law and politics of cooperation and compliance. In: Hepple B (ed) Social and Labour Rights in a Global Context. Cambridge: Cambridge University Press, pp. 236-257.

International Labour Office (2010) Disability in the Workplace: Company Practice, Working Paper No. 3, Geneva: ILO.

Jacquinot P (2009) Les employés handicapés en France : leçons d'intégration, Gestion 3(34) : 116127.

Kahn-Freund O (1969) Industrial relations and the law-retrospect and prospect. British Journal of Industrial Relations 7(3): 301-316.

Klarsfeld A and Ng E (2012) Social regulation and diversity management: a comparative study of France, Canada and the UK. European Journal of Industrial Relations. 18(4): 309-327.

Lee S. and Lee S. (2016) Comparing employment quota systems for disabled people between Korea and Japan. Asian Journal of Human Services. 10: 83-92. 
Levet P (2007) Recruter et intégrer des travailleurs handicapés In : Barth I. \& Falcoz (eds) Le management de La Diversité. Enjeux, Fondements et Pratiques. L’Harmattan: Paris, pp. 5174.

Lawson A (2011) Disability and employment in the Equality Act 2010: opportunities seized, lost and generated. Industrial Law Journal 40(4): 359-383.

Machura S (2016) Civil Justice: Lay Judges in the EU Countries. Onati Socio-Legal Series. 6(2): 235254.

Maggi-Germain N (2010) Les accords «libératoires» sur l'emploi des travailleurs handicapés. La Revue de l'Ires 4(67): 99-121.

Maroto M and Pettinicchio D (2014) The Limitations of Disability Antidiscrimination Legislation: Policymaking and the Economic Well-being of People with Disabilities. Law \& Policy 36(4): 370-407.

Meziani M, Schmitt M-J and Zdravkova Y (2014) ANED 2014 Task 5 - European semester country fiche on disability: France. In: ANED (ed). Leeds: University of Leeds.

Ministry of Justice (2016) Tribunals and gender recognition certificate statistics quarterly: April to June 2015. Available at: www.gov.uk/government/statistics/tribunals-and-gender-recognitioncertificate-statistics-quarterly-april-to-june-2015 (accessed 12 May 2016).

Ministry of Justice (2017) Review of Introduction of fees in the Employment Tribunals Consultation on proposals for reform $\mathrm{Cm}$ 973. London: Ministry of Justice.

O'Brien N (2012) EHRC Challenges and Opportunities. Working Paper Human Rights Consortium. London: University of London.

OECD (2016) Perceived health status. Health at a Glance 2016: OECD Indicators Paris: OECD

Policy Department A (2015) Reasonable Accommodation and Sheltered Workshops for People with Disabilities: Costs and Returns of Investments. Study for the Employment and Social Affairs Committee of the European Parliament, Brussels: European Union.

Pring J (2016) Government set to slash equality watchdog's budget... again. Available at: http://www.disabilitynewsservice.com/government-set-to-slash-equality-watchdogs-budgetagain/ (Accessed 13 March 2017).

Richards J and Sang K. Trade unions as employment facilitators for disabled employees. The International Journal of Human Resource Management 27(14) : 1642-1661.

Romien P (2005) A l'origine de la réinsertion professionnelle des personnes handicapées: la prise en charge des invalides de guerre. Revue Française Des Affaires Sociales 2(2): 229-247.

Sargeant M. Radevich-Katsaroumpa E and Innesti A (2016) Disability Quotas: past or future policy? Economic and Industrial Democracy. 1-18.

Thaler R and Sunstein C (2008) Nudge: Improving Decisions About Health, Wealth and Happiness, UK: Penguin.

Tokson, M. (2015) Judicial Resistance and Legal Change. The University of Chicago Law Review, 82: 901-973.

TUC. 2010. Equality Reps Make a Real Difference to UK Workplaces. www.tuc.org.uk/equalityissues/equality-reps-make-real-difference-uk-workplaces (accessed 5 April 2016).

Tyler T and Blader S (2005) Can businesses effectively regulate employee conduct? The antecedents of rule following in work settings. Academy of Management Journal 48(6): 1143-1158.

Waddington L (2000) Changing attitudes to the rights of people with disabilities in Europe. In: Cooper J (ed) Law, Rights and Disability. London: Jessica Kingsley, pp. 33-57.

William L (2016) The implementation of equality legislation: the case of disabled graduates and reasonable adjustments. Industrial Relations Journal 47(4): 341-359.

\section{Author biographies}

Susan Corby is Professor of Employment Relations at the University of Greenwich, UK Laura William is Senior Lecturer in Human Resource Management and Organisational Behaviour at the University of Greenwich, UK 
European Journal of Industrial Relations Accepted Version

Sarah Richard is a Lecturer in Human Resource Management and Organisational Behaviour at EM Strasbourg Business School, University of Strasbourg, France 
Table 1: Employment rate by disability and gender 2012

\begin{tabular}{llll}
\hline \multirow{2}{*}{ France } & Disabled \% & Not disabled \% & Total population \% \\
& 53.6 (men + women) & 72.6 (men + women) & 69.1 (men + women) \\
& 51.3 (females) & 69.0 (females) & 65.6 (females) \\
UK & 56.2 (males) & 76.3 (males) & 72.8 (males) \\
& 45.9 (men + women) & 80.1 (men + women) & 74.4 (men + women) \\
& 44.6 (females) & 75.3 (females) & 69.9 (females) \\
& 47.4 (males) & 84.9 (males) & 79.1 (males) \\
\hline
\end{tabular}

Source EU-SILC 2012 from final report by S. Grammenos (2014) for ANED Note: The employment rate is calculated by dividing the number of people aged 20-64 in employment by the total population of the same age group and gender (Grammenos, 2014) 
European Journal of Industrial Relations Accepted Version

Table 2: Employment rate by degree of disability 2012

$\begin{array}{lllllll}\text { All } & \begin{array}{l}\text { Moderate } \\ \text { Disability } \\ \%\end{array} & \begin{array}{l}\text { Severe } \\ \text { Disability } \\ \%\end{array} & \begin{array}{l}\text { Disabled } \\ \text { Women } \\ \%\end{array} & \begin{array}{l}\text { Disabled } \\ \text { Men \% }\end{array} & \begin{array}{l}\text { Non- } \\ \text { Disabled } \\ \text { Women }\end{array} & \begin{array}{l}\text { Non- } \\ \text { Disabled } \\ \text { Men \% }\end{array} \\ 74.4 & 65.2 & 23.7 & 44.6 & 47.4 & \begin{array}{l}75.3 \\ 75.9\end{array} \\ 69.1 & 60.5 & 37.1 & 51.3 & 56.2 & 69 & 76.3\end{array}$

Sources: Priestly, M (2014: 5) and Meziani, M et al., (2014:5)

Note: The categories of moderately disabled and severely disabled is based on self-report. 
Table 3: Employment rate by disability and age 2012

\begin{tabular}{lllllllllllll}
\hline & \multicolumn{1}{c}{ Persons with disabilities \% } & \multicolumn{1}{c}{ All persons \% } \\
Age & $\mathbf{1 6 -}$ & $\mathbf{2 5 -}$ & $\mathbf{3 5 -}$ & $\mathbf{4 5 -}$ & $\mathbf{5 5 -}$ & $\mathbf{1 6 -}$ & $\mathbf{1 6 -}$ & $\mathbf{2 5 -}$ & $\mathbf{3 5 -}$ & $\mathbf{4 5 -}$ & $\mathbf{5 5 -}$ & $\mathbf{1 6 - 6 4}$ \\
group & $\mathbf{2 4}$ & $\mathbf{3 4}$ & $\mathbf{4 4}$ & $\mathbf{5 4}$ & $\mathbf{6 4}$ & $\mathbf{6 4}$ & $\mathbf{2 4}$ & $\mathbf{3 4}$ & $\mathbf{4 4}$ & $\mathbf{5 4}$ & $\mathbf{6 4}$ & \\
France & 21.5 & 67.9 & 72.6 & 70.4 & 29.8 & 52.0 & 29.5 & 80.0 & 85.1 & 84.6 & 39.7 & 65.1 \\
UK & 29.5 & 50.0 & 53.1 & 51.1 & 36.8 & 44.6 & 44.3 & 80.0 & 80.1 & 82.9 & 60.5 & 70.5
\end{tabular}

SILC 2012 from final report by S. Grammenos (2014) for ANED 